\title{
The production of pharmaceutical proteins from the milk of transgenic animals *
}

\author{
LM Houdebine \\ INRA, unité de différenciation cellulaire, 78352 Jouy-en-Josas cedex, France
}

(Received 12 June 1995; accepted 7 September 1995)

\begin{abstract}
Summary - The preparation of recombinant proteins of pharmaceutical interest from the milk of transgenic animals is becoming a reality. No protein has reached the market yet but several have been prepared in large quantities not only from laboratory animals but also from ruminants (goat and sheep) and pigs. Rabbit appears more and more to be an intermediate animal well adapted for the preparation of limited amounts of proteins. Several problems remain to be solved to optimize the method. The expression level of genes of interest associated with milk protein gene control regions is usually unpredictable. The recombinant proteins secreted in milk are not always in a satisfactory biochemical form. Cleavage and glycosylation are not always carried out correctly. The problem of the possible presence of agents pathogenic for humans in proteins extracted from milk is not completely solved. Prions have not been found in mammary glands and other milk pathogens may be controlled using good practice in breeding.
\end{abstract}

recombinant protein / transgenic animal / milk

Résumé - Production de protéines d'intérêt pharmaceutique à partir du lait d'animaux transgéniques. La préparation des protéines recombinantes d'intérêt pharmaceutique à partir du lait d'animaux transgéniques est en train de devenir une réalité industrielle. Aucune protéine n'est encore sur le marché mais plusieurs sont produites en abondance non seulement par des animaux de laboratoire mais aussi par des ruminants (chèvre et mouton) ainsi que par des porcs. Le lapin apparaît de plus en plus comme un animal intermédiaire bien adapté pour la préparation de quantités limitées de protéines. Des problèmes restent encore à résoudre pour optimiser la méthode. Le taux d'expression des gènes d'intérêt associés aux éléments régulateurs des gènes des protéines du lait reste le plus souvent imprévisible. Les protéines produites dans le lait ne sont pas toujours sous une forme biochimique satisfaisante. Certains clivages ainsi que certaines glycosylations ne sont parfois réalisés que partiellement. Le problème de la présence éventuelle d'agents pathogènes pour l'homme dans les préparations de protéines recombinantes issues du lait n'est pas complètement résolu. Cet obstacle ne paraît pas infranchissable. Les prions ne semblent en effet pas présents dans la glande mammaire et le lait et la présence d'autres agents pathogènes peut probablement être contrôlée par de bonnes pratiques d'élevage.

\section{protéine recombinante / lait / animal transgénique}

* This review was written for the 6th European Congress of Biotechnology which took place in Nice, 20-24 February, 1995. 
The idea that the milk from transgenic animals could be the source of recombinant pharmaceutical proteins was suggested several years ago. The first experimental demonstration that this goal can be reached was given by Simons et al (1987) who succeeded in producing sheep $\beta$-lactoglobulin in the milk of transgenic mice.

To obtain a protein not naturally secreted in milk, gene constructs containing the regulatory region of a milk protein gene fused to the coding region of the gene of interest must be prepared. The promoter regions from most of the milk protein genes from different species are used for this purpose. The promoter from $\alpha S_{1}-\beta$-caseins, $\beta$-lactoglobulin, whey acidic protein (WAP), $\alpha$ lactalbumin and even the long terminal repeat (LTR) from mouse mammary tumor virus (MMTV) have thus been fused to a variety of genes and used to generate transgenic mice, rats, rabbits, goats, sheep, pigs and cows. Probably more than 50 foreign proteins have been produced in this way in the milk of transgenic mammals. The published data was reported in a recent review (Houdebine, 1994). Since this review was published, additional proteins have been obtained in milk. Among these proteins are human lysozyme (Maga et al, 1994), human insulin-like growth factor-1 (IGF-1) (Maga et al, 1994), bovine chymosin (Brem et al, 1995), human plasminogen activator (Riego et al, 1993; Ebert et al, 1994), human growth hormone (Tojo et al, 1993; Ninomiya et al, 1994), human $\gamma$ interferon (Dobrovolsky et al, 1993), human lactoferrin (Platenburg et al, 1994), human erythropoietin (Hyttinen et al, 1994; Castro et al, 1995), human protein $C$ (Drohan et al, 1994; Paleyanda et al, 1994; Wei et al, 1995), and human albumin (Barash et al, 1993; Hurwitz et al, 1994).

Although little doubt remains on the use of transgenic animals as living fermentor, a certain number of problems are still to be solved before this method can become a common industrial process to produce recombinant proteins.

\section{THE GENERATION OF TRANSGENIC MAMMALS}

The first transgenic mouse was obtained 13 years ago. The method originally defined for mouse and relying on the direct microinjection of gene into the pronucleus of one-cell embryos has been extended to other mammals. Minor adaptations are sufficient to obtain many transgenic rats and rabbits. For farm animals, the yield of transgenics is dramatically low in most cases. Injecting a polycation-DNA complex instead of DNA into cytoplasm, although of moderate efficiency, leads to the generation of transgenic animals. This approach may improve the situation when pronuclei are not visible (Velander et al, unpublished data). The availability of embryos is a limiting factor for ruminants. It is now possible to generate a number of one-cell-stage embryos from cow ovary at a low cost by performing in vitro oocyte maturation and fertilization and to use them for transgenesis (Krimpenfort et al, 1991; Hyttinen et al, 1994). The in vitro generation of embryo from ovary has been extended successfully to sheep and goat $(\mathrm{N}$ Crozet et al, personal communication). The same is not true for porcine embryos at present.

To tentatively reduce the number of recipient females, embryos can be cultured until the blastocyst stage. Only those that were not damaged by the micromanipulation remain at the end of the culture and are candidates to be transferred to females.

The identification of transgenic embryos at the blastocyst stage is theoretically possible by using PCR, starting from a few blastomers. In practice, this method is poorly reliable, due to traces of remaining unintegrated DNA which gives numerous false positives (King and Wall, 1988; Ninomiya et 
al, 1989). Another method based on the discrimination of DNA methylation in the original insert and in the integrated gene may be used (Cousens et al, 1994). Fluorescence in situ hybridization, which proved to be a simple and reliable method to detect transgenes in newborn animals (Swiger et al, 1995), might be helpful in identifying transgenic embryos using isolated blastomers. The coinjection of reporter genes, such as that coding for vargula luciferase but not involving an invasive test on blastocysts, may be an attractive alternative (Thompson et al, 1995). This reporter gene has been associated with the heat stock protein 70 gene promoter and the matrixattached regions (MAR) from human interferon- $\beta$ gene. With such a gene construct, the vargula luciferase can be synthesized, secreted under heat stock and measured in the blastocyst culture medium. The presence of the MARs in the gene construct favours the expression of the integrated DNA and is expected to identify the blastocysts in which the microinjected DNA is integrated and to eliminate those in which unintegrated DNA is still present. A reliable and easy method to identify genuine transgenic blastocysts therefore remains unavailable for the time being.

The transfer of foreign genes through embryonic stem (ES) cells or primordial germ cells (McLaren, 1992) remains impossible so long as these cells cannot be obtained in a reliable manner in species other than mouse. The recent observation that spermatogonia can colonize a foreign testis after a direct microinjection in this tissue and give birth to normal mice in good yield opens new avenues (Brinster and Avarbock, 1994; Brinster and Zimmermann, 1994). Gene transfer through spermatogonia awaits additional experiments showing that these cells can be cultured, transfected and retain their capacity to differentiate to functional spermatozoa after reimplantation into recipient testis.

\section{THE CONSTRUCTION OF EFFICIENT VECTORS}

Many experiments have led to the conclusion that native genes are often efficiently expressed as transgenes whereas their cDNA counterparts are not. The presence of intron, which is generally not required in cultured cells, is thus of paramount importance for transgenes (Brinster et al, 1988; Palmiter et al, 1991). Several studies did not reveal which combinations of promoters, introns and terminators are the best to obtain high and predictable expression of cDNA in transgenic animals (Palmiter et al, 1991). Selecting the best introns, $5^{\prime}-$ and $3^{\prime}$ untranslated regions and terminators to be associated with the promoter of a given milk protein gene is a possible approach. In vitro and in vivo studies have thus shown that the intron from SV40 early genes is much less efficient than the intron from SV40 late genes and the SIS generic intron (Petitclerc et al, 1995). Some gene constructs containing a given cDNA associated with efficient introns and transcription terminators may however be much less efficient in vivo than the corresponding genomic fragment, although they were significantly more potent in cultured cells (Petitclerc et al, 1995). Introducing the foreign cDNA in the middle of milk protein genes, keeping some of their introns and exons in the cDNA situated before and after proved to be efficient in several cases (Brem et al, 1994; Drohan et al, 1994; Hyttinen et al, 1994; Maga et al, 1994; Brem et al, 1995). Using P1 phage or YAC vectors may be useful if long fragments of DNA surrounding milk protein genes or if long foreign genes are to be used. The coinjection of 2 overlapping complementary regions which recombine in vivo may also be performed. This simple procedure proved to be efficient in several species, including rabbit to regenerate functional genes from 2 pieces. At least $60 \%$ of the transgenic rabbits obtained after coinjections of overlapping DNA fragments containing the rabbit WAP 
promoters and human factor VIII CDNA harboured a reconstituted complete gene (Attal et al, unpublished results).

Promoters from milk protein genes used so far show quite different potency. The most efficient promoters seem to be those from ruminant $\alpha S_{1}$-casein (Brem et al, 1994; Platenburg et al, 1994), $\beta$-casein (Ebert et al, 1994; Maga et al, 1994), sheep $\beta$-lactoglobulin (Barash et al, 1993; Brash et al, 1994; Hurwitz et al, 1994; Platenburg et al, 1994) and rabbit WAP (Bischoff et al, 1992; Devinoy et al, 1994). A distribution of the upstream regulatory regions specific of each species may explain some of these differences.

The expression of transgenes is generally highly influenced by their chromatin environment. A few genes are expressed independently of the integrating site. This is the case for sheep $\beta$-lactoglobulin (Whitelaw et $a l, 1992)$ and rat WAP gene (Krnacik et al, $1995)$. This is not true when the $\beta$-lactoglobulin gene promoter is associated with a foreign gene (Barash et al, 1994). In most cases, the DNA sequences responsible for transgene insulation have not been defined. AT-rich MAR have been shown to amplify and insulate integrated genes. This was observed to some extent when chicken lysozyme MAR insulating region was associated with mouse WAP promoter (McKnight et al, 1992). No effect was seen when the MAR located in the $3^{\prime}-\mathrm{OH}$ of human apolipoprotein B 100 gene and in the SV 40 genome was added of both side of constructs containing the rabbit WAP gene promoter (Attal et al, unpublished data). Insulating transgenes therefore remains possible so far only in a limited number of cases.

Introducing a foreign cDNA within a milk protein gene by using ES cells and homologous recombination should provide efficient promoter, introns, terminators and insulators. This technical approach was successfully used to replace mouse $\alpha$-lactalbumin and $\beta$-casein genes by homologous inactive mutated genes (Kumar et al, 1994; Stinnakre et al, 1994). These preliminary successes suggest that foreign proteins will be produced in milk of farm animals when functional ES cells are available.

\section{THE PREDICTION OF GENE CON- STRUCT EFFICIENCY}

Evaluating the potency of gene constructs in vitro before using them to generate transgenics would be very helfpul. Indeed, a relatively long time elapses between the construction of the genes and the measurement of the foreign proteins in milk (especially of course when males are founders), even when transgenic mice are used.

The mouse mammary cell line $\mathrm{HC} 11$ (Ball et al, 1988) can be utilized to evaluate the efficiency of gene constructs. All researchers admit however that the correlation between the potency of a construct in $\mathrm{HC} 11$ cells and transgenics is poor (Petitclerc et al, 1995).

Transgenic mice are usually predictive of what will be observed in other transgenic mammals. In one case at least, however, a gene construct containing the mouse WAP promoter and the human protein $\mathrm{C}$ gene was poorly efficient in mice and of quite acceptable potency in the pig (Velander et al, 1992). Unexpectedly also, the same gene construct was ectopically expressed in sheep (Wall et al, 1995) but not in pig.

Introducing a gene directly into the mammary gland is possible. This was achieved using cationic lipids (MA Sirard, personal communication), biolistics (Furth et al, 1992), and retroviral vectors (Archer et al, 1994). The expression of the gene was then low. It could be higher if gene transfer was carried out with the available potent adenoviral vectors. Whatever happens, this procedure is not expected to be able to replace transgenesis to express large amounts of foreign proteins in many animals and it has little 
chance of allowing a good prediction of the efficiency of gene constructs used as transgenes. Indeed, these methods are in vivo transfection and the foreign genes are not then submitted to the numerous modifications of chromatin which occur during embryo development and organogenesis. The direct gene transfer into functional mammary gland may however provide interesting information on the capacity of the mammary cell to correctly modify a given foreign protein post-translationally.

\section{THE CHOICE OF THE ANIMAL SPECIES}

For the production of very large amounts of foreign protein (more than 100 tons per year), transgenic cows seem the most appropriate. For quantities higher than $1 \mathrm{~kg}$ per year, sheep, goats or even pigs are valuably used. When no more than $1 \mathrm{~kg}$ of recombinant protein per year is needed, rabbits which can be milked with an adapted machine (Lebas, 1970; Duby et al, 1993), may be attractive, due to the relatively low cost of transgenic generation; rabbit also appears to be appropriate as a transition animal to obtain easily sufficient amounts of recombinant proteins for the study of their biochemical and biological properties before using larger animals to produce these proteins on an industrial scale.

Mice can provide only very limited amounts of milk. Milking these animals is possible. It is also easy to collect the whole milk from mammary glands by keeping them on ice for a few hours (Stinnakre et al, 1992).

\section{THE BIOLOGICAL EFFECTS OF THE RECOMBINANT PROTEINS ON HEALTH OF TRANSGENIC ANIMALS}

Most of the recombinant proteins secreted in milk of transgenic animals are to be used potentially as pharmaceuticals for humans. Most of these proteins are biologically active in various mammals. The ectopic and nontemporally regulated expression on the transgenes proved to have detrimental effects on animals. Mouse WAP led to milchlos phenotype (Burdon et al, 1991). Human growth hormone $(\mathrm{hGH})$ induced subfertility and gigantism in mice (Devinoy et al, 1994). Human erythropoietin cDNA fused to rabbit WAP promoter led to a marked accumulation of red blood cells, a delay in growth, a severe subfertility and a premature death of transgenic rabbits (Attal et al, unpublished data).

Ectopic or non-temporally regulated expression of transgenes might be significantly attenuated by adding insulators to the constructs (see above) or by controlling the expression of the transgenes by an external inducer such as tetracyclin (Furth et al, 1994).

An induced homologous recombination using the cre-lox system (Barinaga, 1994) might also contribute to reduced expression of the transgenes out of the lactation period.

An improvement of the specificity of transgene expression might be obtained by replacing a milk protein gene by the gene of interest. This was achieved recently in mice expressing human $\alpha$-lactalbumin gene instead of their own (Stacey et al, 1994, 1995). It should be noted that this approach remains limited to mice so long as ES cells are not available in other species. Moreover, the in situ association of a foreign gene of interest with the regulatory sequence of a milk protein gene using homologous recombination may be not efficient in all cases.

On the other hand, whey proteins such as $\alpha$-lactalbumin or WAP are spontaneously transferred from milk to blood during lactation (Grabowsky et al, 1991). This is also the case for recombinant proteins such as human growth hormone (GH) (Devinoy et 
al, 1994). In some cases, even when the expression of the transgene is prefectly controlled, the health of the animals may be severely altered by the recombinant proteins transferred from milk to blood.

\section{PURIFICATION OF THE RECOMBINANT PROTEINS FROM MILK}

Milk is not an exceedingly complex biological fluid. It contains a large quantity of a few proteins and only limited proteolytic activity. Conventional methods to purify proteins seem appropriate to isolate recombinant proteins from whey (Ebert et al, 1991; Wilkins and Kuys, 1992). In particular cases, when recombinant proteins are hydrophobic, they are secreted with lipid globules. This was the case for human cystic fibrosis transmembrane conductance regulator (CFTR) (Di Tullio et al, 1992).

The major concern with recombinant proteins from animal origin is not the classical biochemical purity. The presence of pathogens in the purified proteins may be detrimental for humans as soon as the proteins are injected, and in some cases, such as albumin or haemoglobin, in very large amounts. The presence of prions is a potential problem. The capacity of these molecules to be pathogens for other species is not well documented. In case this problem cannot be solved the inactivation of the PrP gene by homologous recombination can be envisaged although presently only in mouse. In the mouse, the inactivation of this gene did not alter greatly the health of the animals. However, the problem may be not so crucial since no prion has been found so far in mammary gland extract and milk from cows suffering from bovine spongiform encephalopathy. Transgenic mice harbouring sheep PrP gene instead of their own might be used to detect the presence of prion in fractions isolated from sheep milk.

\section{THE BIOCHEMICAL STRUCTURE OF THE RECOMBINANT PROTEINS FROM MILK}

Animals cells rather than bacteria or yeast are used to produce a certain number of recombinant proteins to tentatively obtain polypeptides with all the post-translational modifications. It is by no means certain that the mammary gland can perform all these modifications in a convenient manner. This seems unfortunately to be the case. Human$\alpha_{1}$-antitrypsin from sheep milk (A Colman, unpublished data), human anti-thrombin III from goat milk (ES Cole, unpublished data) are not fully glycosylated. The in vitro enzymatic addition of the missing terminal sialic acid increases significantly the half-life of the protein in vivo without apparently altering its biological activity.

Human protein $\mathrm{C}$ precursor from pig milk is not completely processed and not fully $\gamma$-carboxylated (Drohan et al, 1994).

Most likely, the mammary cells of different species do not have exactly the same enzymatic equipment for protein maturation. It may be therefore hazardous in some cases to extrapolate from model animals such as the mouse and the rabbit to predict the structure of a given recombinant protein in pig or ruminants.

Modifying the enzymatic equipment of the mammary cell through transgenesis to improve maturation of recombinant proteins is conceivable. It may however lead to disfunction of the mammary gland in some cases and a long investigation is needed before such an approach can be envisaged.

The fact that recombinant proteins from milk do not always have the same structure as their native counterpart may be of limited importance. The possible sideeffects of the recombinant proteins extracted from milk must thus be evaluated case by case. 


\section{ALTERNATIVE PRODUCTION SYSTEMS}

Milk is presently considered as the best biological fluid to produce recombinant proteins from animals. Blood may be appropriate in some cases, when the recombinant proteins are not too unstable or too toxic for the animals. This was the case for human $\alpha_{1}$-antitrypsin which has been produced from liver at the concentration of $1 \mathrm{mg} / \mathrm{ml}$ with apparently a glycosylation similar to the native protein (Massoud et al, 1991). Human haemoglobin (Swanson et al, 1992) and peptides have also been produced in reticulocytes from transgenic animals. The purification of human proteins from the blood of transgenic animals may not be easy in some cases. Blood may thus be of limited interest in practice.

Egg white might become, in the future, a good source of recombinant proteins by transgenic birds.

Transgenic plants can also be the source of recombinant proteins. Hepatitis B surface antigen has been prepared in this manner (Mason et al, 1992). Plants may be appropriate when very large amounts of simple polypeptides must be prepared without any pathogens for humans. Human albumin and haemoglobin are good candidates to be extracted from transgenic plants.

\section{OTHER USES OF TRANSGENESIS TO EXPRESS FOREIGN GENES IN THE MAMMARY GLAND}

Gene transfer is used to study growth, differentiation (Jhappan et al, 1993; Pierce et al, 1993) and oncogenesis (Cardiff and Muller, 1993) of the mammary gland or other aspects of mammary gland function. Milk represents about $30 \%$ of the proteins of human food in rich countries. Its composition may be changed to improve yield or quality of the product for dairy industry. This may be achieved by modifying the concentration or amino acid composition of milk proteins.

Milk is not only a food. It contains various growth factors, anti-pathogen proteins such as lysozyme, lactoferrin, antibodies. Milk may become a vehicle to provide humans with number of factors and it may thus become a novel food (Clark, 1992; Yom et al, 1993). Conventional gene transfer, targeted gene knock-out and mutation in farm animals may greatly contribute to reaching this goal.

\section{REFERENCES}

Archer JS, Kennan WS, Gould MN, Bremel RD (1994) Human growth hormone (hGH) secretion in milk of goats after direct transfer of the hGH gene into the mammary gland by using replication-defective retrovirus vectors. Proc Natl Acad Sci USA 91, 68406844

Ball RK, Friis RR, Schoenenberger CA, Doppler W, Groner B (1988) Prolactin regulation of beta-casein gene expression and of a cytosolic 120-kd protein in a cloned mouse mammary epithelial cell line. $E M B O$ $J 7$, 2089-2095

Barash I, Baruch A, Nathan M, Shani M, Hurwitz DR (1993) HSA production by mammary explants of virgin transgenic mice: a reliable tool for predicting levels of secretion into milk. Anim Biotechnol 4, 203215

Barash I, Faerman A, Ratovitsky T et al (1994) Ectopic expression of $\beta$-lactoglobulin/human serum albumin fusion genes in transgenic mice: hormonal regulation and in situ localization. Transgenic Res 3, 141-151

Barinaga M (1994) Knockout mice: round 2. Science 265, 26-28

Bischoff R, Degryse E, Perraud F et al (1992) A 17.6 $\mathrm{kb}$ region located upstream of the rabbit WAP gene directs high level expression of a functional human protein variant in transgenic mouse milk. FEBS Lett $305,265-268$

Bowen RA, Reed ML, Schnieke A et al (1994) Transgenic cattle resulting from biopsied embryos: expression of c-ski in a transgenic calf. Biol Reprod 50 , 664-668

Brem G, Hartl P, Besenfelder U, Wolf E, Zinovieva N, Pfaller R (1994) Expression of synthetic cDNA sequences encoding human insulin-like growth factor-1 (IGF-1) in the mammary gland of transgenic rabbits. Gene 149, 351-355 
Brem G, Besenfelder U, Zinovieva N, Seregi J, Solti L, Hart P (1995) Mammary gland specific expression of chymosin constructs in transgenic rabbits. Theriogenology 43, 175

Brinster RL, Avarbock MR (1994) Germline transmission of donor haplotype following spermatogonial transplantation. Proc Natl Acad Sci USA 91, 11303-11307

Brinster RL, Zimmermann JW (1994) Spermatogenesis following male germ-cell transplantation. Proc Natl Acad Sci USA 91, 11298-11302

Brinster RL, Allen JM, Behringer RR, Gelinas RE, Palmiter RD (1988) Introns increase transcriptional efficiency in transgenic mice. Proc Natt Acad Sci USA 85, 836-840

Burdon T, Wall RJ, Shamay A, Smith GH, Henninghausen $L$ (1991) Over-expression of an endogenous milk protein gene in transgenic mice is associated with impaired mammary alveolar development and a milchlos phenotype. Mech Dev 36, 67-74

Cardiff RD, Muller WJ (1993) Transgenic mouse models of mammary tumorigenesis. The Molecular Pathology of Cancer, Cancer Surveys 16

Castro FO, Aguirre A, Fuentes P, Ramos B, Rodriguez $A$, de la Fuente J (1995) Secretion of human erythropoietin by mammary gland explants from lactating transgenic rabbits. Theriogenology 43,184

Clark AJ (1992) Prospects for the genetic engineering of milk. Mol Cell Biochem 49, 121-127

Cousens C, Carver AS, Wilmut I, Colman A, Garner I, O'Neill GT (1994) Use of PCR-based methods for selection of integrated transgenes in preimplantation embryos. Mol Reprod Develop 39, 384-391

Devinoy E, Thépot D, Stinnakre MG et al (1994) High levels of production of human growth hormone in the milk of transgenic mice: the upstream region of the rabbit whey acidic protein (WAP) gene targets transgene expression to the mammary gland. Transgenic Res 3, 79-89

Di Tullio P, Cheng SH, Marshall et al (1992) Production of cystic fibrosis transmembrane conductance regulator in the milk of transgenic mice. Bio/Technology 10, 74-77

Dobrovolsky VN, Lagutin OV, Vinogradova TV, Frolova LS, Kuznetsov VP, Larionov OA (1993) Human $\gamma$-interferon expression in the mammary gland of transgenic mice. FEBS 319, 181-184

Drohan WN, Zhang DW, Paleyanda RK et al (1994) Inefficient processing of human protein $\mathrm{C}$ in the mousse mammary gland. Transgenic Res $3,355-$ 364

Duby RT, Cunniff MB, Belak JM, Balise JJ, Robl JM (1993) Effect of milking on collection of milk from nursing New-Zealand white rabbits. Anim Biotechnol 4, 31-42

Ebert KM, Selgrath JP, DiTullio P et al (1991) Transgenic production of a variant of human tissue-type plasminogen activator in goat milk: generation of transgenic goats and analysis of expression. Bio/Technol 9, 835-838

Ebert KM, DiTullio P, Barry CA et al (1994) Induction of human tissue plasminogen activator in the mammary gland of transgenic goats. Bio/Technology 12 , 699-702

Furth PA, Shamay A, Wall RJ, Hennighausen L (1992) Gene transfer into somatic tissues by jet injection. Anal Biochem 205, 365-368

Furth PA, St Onge L, Böger $\mathrm{H}$ et al (1994) Temporal control of gene expression in transgenic mice by a tetracycline-responsive promoter. Proc Natl Acad Sci USA 91, 9302-9306

Grabowsky H, Le Bars D, Chene N et al (1991) Rabbit whey acidic protein concentration in milk, serum, mammary gland extract, and culture medium. J Dairy Sci 74, 4143-4154

Houdebine LM (1994) Production of pharmaceutical proteins from transgenic animals. J Biotechno/ 34, 269287

Hurwitz DR, Nathan M, Barash I, llan N, Shani M (1994) Specific combinations of human serum albumin introns direct high level expression of albumin in transfected COS cells and in the milk of transgenic mice. Transgenic Res 3, 365-375

Hyttinen JM, Peura T, Tolvanen M et al (1994) Generation of transgenic dairy cattle from transgene-analyzed and sexed embryos produced in vitro. Bio/Technology 12, 606-608

Jhappan C, Geiser AG, Kordon EC et al (1993) Targeting expression of a transforming growth factor beta1 transgene to the pregnant mammary gland inhibits alveolar development and lactation. EMBO J 12 , 1835-1845

King D, Wall RJ (1988) Identification of specific gene sequences in preimplantation embryos by genomic amplification: detection of a transgene. Mol Reprod Develop 1, 57-62

Krimpenfort $P$, Rademakers A, Eyestone $W$ et al (1991) Generation of transgenic dairy cattle using in vitro embryo production. Bio/Technology 9, 844-847

Krnacik MJ, Li S, Liao J, Rosen JM (1995) Positionindependent expression of whey acidic protein transgenes. J Biol Chem 270, 11119-11129

Kumar R, Clarke AR, Hooper ML et al (1994) Milk composition and lactation of $\beta$-casein-deficient mice. Proc Natl Acad Sci USA 91, 6138-6142

Lebas $F(1970)$ Description d'une machine à traire les lapines. Ann Zootech 19, 223-228

Maga EA, Anderson GB, Huang MC, Murray JD (1994) Expression of human lysozyme mRNA in the mammary gland of transgenic mice. Transgenic Res 3, 3642

Mason HS, Lam DMK, Arntzen CJ (1992) Expression of hepatitis $B$ surface antigen in transgenic plants. Proc Natl Acad Sci USA 89, 11745-11749 
Massoud M, Bischoff R, Dalemans W et al (1991) Expression of active recombinant human alpha1-antitrypsine in transgenic rabbits. J Biotech 18, 193-204

McKnight RA, Shamay A, Sankaran L, Wall RJ, Henninghausen $L$ (1992) Matrix-attachment regions can impart position-independent regulation of a tissuespecific gene in transgenic mice. Proc Natl Acad $\mathrm{Scl}$ USA 89, 6943.6947

McLaren A (1992) The quest for immortality. Nature (Lond) 359, 482-483

Ninomiya T, Hoshi M, Mizuno A, Nagao M, Yuki A (1989) Selection of mouse preimplantation embryos carrying exogenous DNA by polymerase chain reaction. Mol Reprod Dev 1, 242-248

Ninomiya T, Hirabayashi M, Sagara J, Yuki A (1994) Functions of milk protein gene 5 '-flanking regions on human growth hormone gene. Mol Reprod Dev $37,276-283$

Paleyanda RK, Zhang DW, Hennighausen L, McKnight RA, Lubon $H$ (1994) Regulation of human protein $C$ gene expression by the mouse WAP promoter. Transgenic Res 3, 335-343

Palmiter RD, Sandgren EP, Avarbock MR, Allen DD, Brinster RL (1991) Heterologous introns can enhance expression of transgenes in mice. Proc Natl Acad Sci USA 88, 478-482

Petitclerc D, Attal J, Théron MC et al (1995) The effect of various introns and transcription terminators on the efficiency of expression vectors in various cul-

- tured cell lines and in the mammary gland of transgenic mice. J Biotechno/ 40, 169-178

Pierce Jr DF, Johnson MD, Matsui $Y$ et al (1993) Inhibition of mammary duct development but not alveolar outgrowth during pregnancy in transgenic mice expressing active TGF-beta1. Genes Dev 7, 23082317

Platenburg GJ, Kootwijk EPA, Kooiman PM et al (1994) Expression of human lactoferrin in milk of transgenic mice. Transgenic Res 3, 99-108

Riego E, Limonta J, Aguilar A et al (1993) Production of transgenic mice and rabbits that carry and express the human tissue plasminogen activator cDNA under the control of a bovine alpha $S_{1}$ casein promoter. Theriogenology 39, 1173-1185

Simons JP, McClenaghan M, Clark AJ (1987) Alteration of the quality of milk by expression of sheep beta-lactoglobublin in transgenic mouse. Nature (Lond) 328 , 530-532

Stacey A, Schnieke A, McWhir J, Cooper J, Colman A, Melton DW (1994) Use of double-replacement gene targeting to replace the murine $\alpha$-lactatbumin gene with its human counterpart in embryonic stem cells and mice. Mol Cell Biol 14, 1009-1016
Stacey A, Schnieke A, Kerr M et al (1995) Lactation is disrupted by $\alpha$-lactalbumin deficiency and can be restored by human $\alpha$-lactalbumin gene replacement in mice. Proc Natl Acad Sci USA 92, 28352839

Stinnakre MG, Devinoy E, Thépot D et al (1992) Quantitative collection of milk and active recombinant proteins from the mammary gland of transgenic mice. Anim Biotechnol 3, 245-255

Stinnakre MG, Vilotte JL, Soulier S, Mercier JC (1994) Creation and phenotype analysis of $\alpha$-lactalbumindeficient mice. Proc Natl Acad Sci USA 91, 65446548

Swanson ME, Martin MJ, O'Donnell JK et al (1992) Production of functional human hemoglobin in transgenic swine. Bio/Technol 10, 557-559

Swiger RR, Tucker JD, Heddle JA (1995) Detection of transgenic animals without cell culture using fluorescence in situ hybridization. BioTechniques 18 , $952-957$

Thompson EM, Adenot P, Tsuji FI, Renard JP (1995) Real time imaging of transcriptional activity in live mouse preimplantation embryos using a secreted luciferase. Proc Natl Acad Sci USA 92 (in press)

Tojo H, Tanaka S, Matsuzawa A, Takahashi M, Tachi C (1993) Production and characterization of transgenic mice expressing a hGH fusion gene driven by the promoter of mouse whey acidic protein (mWAP) putatively specific to mammary gland. J Reprod Dev 39, 145-155

Velander WH, Johnson JL, Page RL et al (1992) Highlevel expression of a heterologous protein in the milk of transgenic swine using the CDNA encoding human protein C. Proc Natl Acad Sci USA 89 , 12003-12007

Wall RJ, Rexroad Jr CE, Powell A, Shamay A, McKnight $R$, Henninghausen $L$ (1995) Mouse whey acidic protein gene is expressed ectopically in transgenic sheep. Theriogenology 43, 346

Wei Y, Yarus S, Greenberg NM, Whitsett J, Rosen JM (1995) Production of human surfactant protein $C$ in milk of transgenic mice. Transgenic Res 4, 232-240

Whitelaw CB, Harris S, McClenagham M, Simons JP (1992) Position-independent expression of the ovine beta-lactoglobulin gene in transgenic mice. Biochem J 286, 31-39

Wilkins RJ, Kuys YM (1992) Rapid beta-lactoglobulin genotyping of cattle using the polymerase chain reaction animal. Genetics $23,175-178$

Yom HC, Bremel RD (1993) Genetic engineering of milk composition: modification of milk components in lactating transgenic animals. Am J Clin Nutr 58, 299S$306 \mathrm{~S}$ 